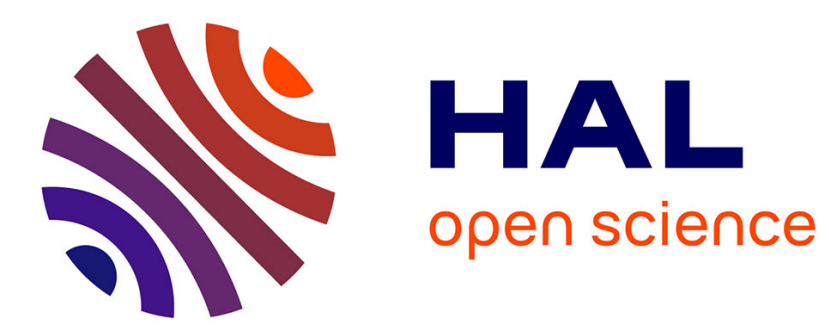

\title{
The Positron as an Industrial Tool
}

J. Goedkoop

\section{To cite this version:}

J. Goedkoop. The Positron as an Industrial Tool. Journal de Physique IV Proceedings, 1995, 05 (C1), pp.C1-227-C1-229. 10.1051/jp4:1995126 . jpa-00253562

\section{HAL Id: jpa-00253562 https://hal.science/jpa-00253562}

Submitted on 1 Jan 1995

HAL is a multi-disciplinary open access archive for the deposit and dissemination of scientific research documents, whether they are published or not. The documents may come from teaching and research institutions in France or abroad, or from public or private research centers.
L'archive ouverte pluridisciplinaire HAL, est destinée au dépôt et à la diffusion de documents scientifiques de niveau recherche, publiés ou non, émanant des établissements d'enseignement et de recherche français ou étrangers, des laboratoires publics ou privés. 


\title{
The Positron as an Industrial Tool
}

\author{
J.A. Goedkoop \\ De Rougemont-Nes 1, 1862 AB Bergen, The Netherlands
}

\begin{abstract}
Europhysics Industrial Workshops are to deal with physics holding clear promise of industrial application. The question whether positron annihilation is too arcane a subject to fit that description will be examined.
\end{abstract}

Europhysics Industrial Workshops were launched in 1987 by the European Physical Society with the aim to foster exchange between universities and industry on topics in physics showing clear promise of industrial application. Such subjects are identified, and knowledgeable Organizing Chairmen found, by the Society's Action Committee for Applied Physics and Physics in Industry (ACAPPI). Table 1 lists the EIWs that have been held so far or have been announced. As you may note, the one on Positron Annihilation we are concluding today, although number twelve on the list, is actually the eleventh to be held. It has been a pleasure for me, as former chairman of ACAPPI still largely responsible for initiating this exercise, to take part in it, and an honour to have been asked to be the last speaker. I shall use my time to ponder whether this meeting has been what an EIW is intended to be. Of course that question was considered, on the basis of written or oral reports, in ACAPPI after every such meeting. This time I shall be able to do that with fresh in mind what I have seen and heard here and in front of the Workshop-participants.

\section{Participation}

Obviously, if an EIW is to foster exchange of ideas between universities and industry, both will have to be represented. The degree to which they were has varied widely hetween EIWs, but on average we have had almost exactly what we wanted: about fifty participants, with one third coming from universities and one third from industry, the balance being made up by people from the large laboratories, originally governmental, but nowadays increasingly presenting themselves as private firms.

When I now look at this Workshop, with 39 active participants somewhat smaller than what the EPS is accustomed to, I count among them 14 representing universities, 7 from industry and 18 from the large laboratories. One might conclude that industrial participation was below average, but should note that I only included organizations producing some kind of commodity, whereas on the basis of my following remarks I might also have included some of the laboratories who could nowadays be considered service industries.

The mere fact that people from industry take part in an EPS meeting does of course not certify that it is about 'subjects in physics holding clear promise of industrial application'. It does not because most likely they will not be from production divisions, but from the research laboratory, where they do work similar to their colleagues in universities. Another look at Table 1 will show that in fact several 
of the past EIWs were on techniques, such as those made possible by the advent of the scanning tunnelling electron microscope, that are of interest to that category. But others were on products or materials that incorporate recent advances in physics and that are now on the market, such as pyroelectric detectors and other sensors, conducting polymers and structural ceramics. From this it will be clear that in selecting EIW topics the term 'industrial application' has from the beginning been interpreted liberally so as not to be confined to commercial application.

\section{Perceptions of industry}

In another sense, however, the interpretation has been narrow, in fact, largely confined to the electronics industry, the principal exception being the EIW on Structural Ceramics. Of course this is not surprising since the products of that branch are so often the result of recent research in physics. Also, in choosing subjects, ACAPPI is mindful of the interests of the EPS Associate Members, who include most of the large European electronics firms.

Attempts to widen this interpretation also run up to a linguistic barrier. The language of the EPS is English, but one must beware of terms that look like words in other European languages. 'Industry' is one of those: all the continental languages I know have a word quite similar to 'industry', the differences being only in the spelling of the last syllable and in the stress. With few exceptions, those words then refer to the production of material goods, so to the manufacturing and processing industries. In the British media, however, one often encounters reports about the insurance industry and about industrial action by railwaymen, demonstrating that 'industry' in english is meant also to include the service sector. Now it seems to me that if the EPS uses English, it should use it as the British do, and hence EIWs should be allowed to deal with potential application of physics in any human endeavour outside the laboratory and certainly not, as continental physicists seem to feel, limited to manufacturing.

What is more, since even nurses are reported to take industrial action, one might argue that also physics applied in hospitals should be included, and this brings us to the present workshop. In an early stage the Organizing Chairmen did raise the question whether clinical applications of positron annihilation should be included. When this matter was referred to ACAPPI their ruling was, and I still concur, that clinical practice should nowadays indeed be considered an industrial activity. Thus the Organizing Chairmen were free to include medical applications. In the end they decided not to, mainly, I believe, since otherwise the attendance might have been very heterogeneous, with Positron Emission Tomography applied to animate matter dominating the programme. Had they decided otherwise, this workshop, using what I think is the proper terminology, might have been the most industrial one in the list of EIWs.

\section{Presentations in EIW-12}

When now, in light of these considerations, we review what has been presented orally in this Europhysics Industrial Workshop, the first conclusion can only be that once more the electronic industry must be the main potential beneficiary. Leaving off the first and the last sessions, which dealt with more general themes, we find that four of the remaining eight sessions, with 10 invited lectures, concerned the application of positron annihilation spectroscopy (PAS) and lifetime measurements in research on vacancies of other imperfections in semiconductors of various kinds.

Similar laboratory studies were the subject of another 10 papers, presented in three sessions, on other materials: alloys, ceramics, layers and polymers. Also these were clearly of current or potential industrial interest. One paper, in fact, showed PAS leaving the laboratory, to be applied in mobile equipment for non-destructive assessment of material damage. In contrast to the application to semiconductor heterostructures, where length scales are still shrinking, here the requirements are likely to develop in the opposite direction. The same seems true for PET, the subject of the remaining session, which we already saw applied to an aircraft engine.

In addition to the invited papers we had 13 posters. It is interesting to note that, whereas almost half the former were on semiconductors, this was the case for only 4 of the posters. Does this mean that at the grass roots there is a tendency towards other groups of materials? I gladly leave that to the organizers of a future workshop on positron annihilation. 


\section{Public relations}

Those organizers may also want to heed the comments that have been made on the way this field presents itself. Some of these remarks, coming from industry, concerned the way data are plotted, e.g. whereas the 'customer' would expect a plot of vacancy concentration vs. depth, what he gets is something called the 'S-parameter' as a function of positron energy. But also called into question was the very term 'positron annihilation', which sounds even more negative when it is presented as a method for finding 'defects'. In these times when jobs for physicists are hard to find, it may help to point out that the latter are vacancies. But that leaves the 'annilation', for which there is really no excuse since what is observed is not the disappearance of the positron, but the emergence of two photons. This, I would suggest, should be recognized, and a more constructive face presented, by having the next workshop on 'Photon Pair Creation'. At the expense of getting one letter longer, the acronyms PAS and PET would then become, more consistently, PPCS and PPCT, respectively.

\section{TABLE 1 - EUROPHYSICS INDUSTRIAL WORKSHOPS}

\begin{tabular}{|c|c|c|c|}
\hline Number & Dates & Place & Title \\
\hline EIW- 1 & $\begin{array}{r}26-28 \text { April } \\
1987\end{array}$ & $\begin{array}{l}\text { Bad Honnef } \\
\text { (D) }\end{array}$ & Low Resolution Pyroelectric Arrays \\
\hline EIW- 2 & $\begin{array}{r}1-4 \text { November } \\
1987\end{array}$ & $\begin{array}{l}\text { Bad Honnef } \\
\text { (D) }\end{array}$ & Future of Magneto-optical Recording \\
\hline EIW- 3 & $\begin{array}{r}22-24 \text { June } \\
1988\end{array}$ & Rome (I) & SQUID: State of the Art, Perspectives and Applications \\
\hline EIW- 4 & $\begin{array}{r}11-13 \text { October } \\
1989\end{array}$ & $\begin{array}{l}\text { Bad Honnef } \\
\text { (D) }\end{array}$ & Ion Beams in Materials Research and Technology \\
\hline EIW- 5 & 3-6 April 1990 & Petten & Designing with Structural Ceramics \\
\hline EIW- 6 & $\begin{array}{l}\text { 28-30 May } \\
1990\end{array}$ & $\begin{array}{l}\text { Lofthus } \\
\qquad(\mathrm{N})\end{array}$ & Science and Applications of Conducting Polymers \\
\hline EIW- 7 & $\begin{array}{l}18-22 \text { June } \\
1990\end{array}$ & $\begin{array}{l}\text { Leningrad } \\
\text { (SU) }\end{array}$ & Semiconductor Surface Science and Engineering \\
\hline EIW- 8 & $\begin{array}{r}18-21 \text { August } \\
1991\end{array}$ & Davos $(\mathrm{CH})$ & Nanometer-Scale Methods in Technology and Industry \\
\hline EIW- 9 & $\begin{array}{r}25-28 \text { August } \\
1993\end{array}$ & $\begin{array}{l}\text { Oxford } \\
\qquad(\mathrm{GB})\end{array}$ & Acoustical Imaging \\
\hline EIW-10 & $\begin{array}{r}11-13 \text { October } \\
1993\end{array}$ & $\begin{array}{l}\text { Veldhoven } \\
\text { (NL) }\end{array}$ & Nanometer-Scale Methods in X-Ray Technology \\
\hline EIW-11 & $\begin{array}{r}\text { 25-29 April } \\
1994\end{array}$ & $\begin{array}{l}\text { Oherhof } \\
\text { (D) }\end{array}$ & $\begin{array}{c}\text { Thermal Microsensors - Their Bases, Principles and } \\
\text { Applications }\end{array}$ \\
\hline EIW-12 & $\begin{array}{r}\text { 10-12 March } \\
1994\end{array}$ & $\begin{array}{l}\text { Oisterwijk } \\
\text { (NL) }\end{array}$ & Industrial Applications of Positron Annihilation \\
\hline
\end{tabular}

